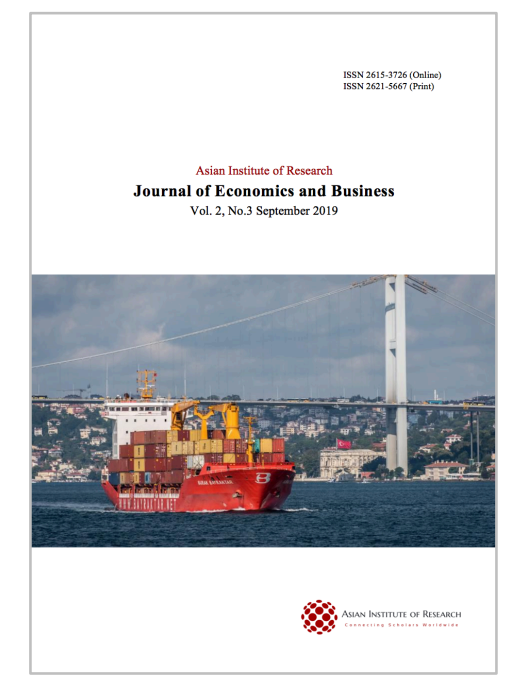

Journal of Economics and Business

Lawson, Judith, Kuanqi, Du, and Geoffrey, Bentum-Micah. (2019), The Impact of Macroeconomic Variables, Investment Incentives and Government Agreements on FDI Inflows in Ghana. In: Journal of Economics and Business, Vol.2, No.3, 1039-1056.

ISSN 2615-3726

DOI: 10.31014/aior.1992.02.03.149

The online version of this article can be found at: https://www.asianinstituteofresearch.org/

Published by:

The Asian Institute of Research

The Journal of Economics and Business is an Open Access publication. It may be read, copied, and distributed free of charge according to the conditions of the Creative Commons Attribution 4.0 International license.

The Asian Institute of Research Journal of Economics and Business is a peer-reviewed International Journal. The journal covers scholarly articles in the fields of Economics and Business, which includes, but not limited to, Business Economics (Micro and Macro), Finance, Management, Marketing, Business Law, Entrepreneurship, Behavioral and Health Economics, Government Taxation and Regulations, Financial Markets, International Economics, Investment, and Economic Development. As the journal is Open Access, it ensures high visibility and the increase of citations for all research articles published. The Journal of Economics and Business aims to facilitate scholarly work on recent theoretical and practical aspects of Economics and Business. 


\title{
The Impact of Macroeconomic Variables, Investment Incentives and Government Agreements on FDI Inflows in Ghana
}

\author{
Judith Lawson ${ }^{1}$, Du Kuanqi ${ }^{1}$, Bentum-Micah Geoffrey ${ }^{2}$ \\ ${ }^{1}$ School of Economics and Management, Nanjing University of Science and Technology, 210094 Nanjing, \\ China. \\ ${ }^{2}$ School of Management Science and Engineering, Jiangsu University, Zhenjiang 212013, China. \\ Correspondence: Du Kuanqi. Tel: +86-13913885961. E-mail address: kqddkq@126.com
}

\begin{abstract}
The last two decades have witnessed an extensive growth and an ever-increasing competition in foreign direct investment (FDI) flows to the developing countries. This has resulted in higher investment incentives offered by the host governments and an increase in the number of bilateral investment treaties (BITs) and regional agreements on investments. This research addresses the effectiveness of selective government policies and investment agreements in attracting FDI flows in developing countries. To achieve this, the impact of economic variables such as presence of infrastructure, cost of labor, annual gross domestic product (GDP) growth, real effective exchange rate, and tax incentives as well as bilateral investment treaties on the inflows of foreign direct investment within a 30-year span in Ghana was examined. The paper employed a regression analysis with the dependent and independent variables being FDI inflows and the listed variables respectively. Additionally, analytical techniques such as heteroskedasticity and Chou test were conducted. From the study, it is observed that inflows of FDI vary within the structural break analyzed and a low percentage of BITs reflect as a contributing factor of FDI. However, national policies proved to play a significant role in attracting FDI into Ghana.
\end{abstract}

Keywords: Foreign Direct Investment, Selective Government Policies, Bilateral Investment Treaties

\section{Introduction}

Capital flows, more especially foreign direct investment (FDI), are one of the major instruments of globalization and international integration of developing countries. There have been tremendous improvements in international trade and according to the World Investment Report, FDI flows in 2013 increased to \$1.45 trillion, with developing countries increasing their share of inflows to (a record level of) 54 percent. This trend in the evolution of foreign inflows has heightened the debate about the main factors influencing the inward investment and how these variables can be tapped and harnessed to maximize inflows in regions. The role of foreign direct investment in the growth process has for long been a topic of intense debate. Although this debate has provided 
rich insights into the relationship between FDI and growth, there is still more room for empirical analysis to examine the causal factors of FDI inflows.

There have been empirical evidences of macro and micro determinants of foreign direct investment inflows in various regions and sectors and rising level of attractiveness of different countries and geographical locations. Developing countries, especially Ghana, are more open to embracing investments in their countries seeing the promising graphs and figures and the potential that inflows can serve the nation and aid in economic balance and stability. With this, tariffs and restrictions previously faced by foreign investors have been replaced by various investment incentives. These stand to pave a way for tariff-free and fair trade amongst investors and host countries. Also emerging are the various bilateral and multilateral investment treaties, which seek to protect and promote FDI, signed between the host government and other countries. All this is to strengthen the trade and increase inflows of FDI in Ghana.

A plethora of evidence and empirical research on the inflows of FDI in Ghana study the relationship between FDI and economic growth using parameters Gross Domestic Product(GDP), GDP growth rate, GNI, Manufacturing Value Added, External Debt Stock, Inflation, Trade, Industry Value-added and Foreign Direct Investment net inflows as percent of GDP (FDI ratio) combining qualitative and quantitative methods. Other studies also determine the macroeconomic factors that influence foreign direct investment inflows to Ghana using co-integration analysis. In this it was found that exchange rate and trade openness were statistically significant. FDI inflows as indicated by many researchers. (Onyeiwu \& Shrestha, 2004), (E. J. W. e. Asiedu, 2006; Hailu \& Finance, 2010; Sekkat \& Veganzones-Varoudakis, 2007), found that FDI flows into Africa are negatively correlated with the level of inflation including many other papers each using macroeconomic parameters or other vectors such as investment incentives as a measure of FDI in Ghana.

Until recently, there was a strong consensus in the literature that multinational corporations (MNCs) invest in specific locations mainly because of strong economic fundamentals in the host countries for example, large market size, stable macroeconomic environment etc.(Dunning \& Narula, 2003; Globerman \& Shapiro, 1999; Shapiro \& Globerman, 2001). However with growing consensus and integration of FDI and increased competition amongst host countries in attracting FDI inflows, one may decide to review the literature that focuses more on the macro economic variables considered when measuring the ability of a country to attract investments to a more complex outlook which does not only involve economic determinants but also government incentives that is national policies as well as bilateral, regional and multilateral agreements in the determination of FDI inflows in a particular region. This begs one to revisit and reconsider the underlying literature on determinants and impacts of inward FDI in the country Ghana.

(Brewer, 1993) discusses the array of government policies that can directly and indirectly affect FDI through their effects on market imperfections. It is realized there that some policies implemented by the governmental institution could either serve as increase or decrease to the attractions of FDI. It is also found that empirical evidence on the impact of selected governmental policies on FDI is difficult to quantify or at times considered ambiguous (Driffield \& Taylor, 2000; Grubert \& Mutti, 1991; Kumar \& Pradhan, 2002; Loree \& Guisinger, 1995) find a positive effect of investment incentives and a negative impact of performance requirements imposed by the host governments on inward FDI flows. (Review, 1996) reports that incentives can have an effect on attracting FDI only at the margin, especially when one considers the type of incentive and the type of project.

However, some studies e.g., (Contractor, 1991), finds that policy changes have a weak influence on FDI inflows. (Alfaro, Chanda, Kalemli-Ozcan, \& Sayek, 2004; Villela \& Barreix, 2002) conclude that incentives are generally ineffective once the role of fundamental determinants of FDI is taken into account. This view is also supported by (Hoekman \& Saggi, 2000) who conclude that although useful for attracting certain types of FDI, incentives do not seem to work when applied at an economy-wide level. In a recent paper, (Nunnenkamp, 2002) argues that little has changed since 1980s and traditional market-related determinants are still dominant factors attracting FDI. Further, (Blomström, Kokko, \& Mucchielli, 2003) have discussed whether FDI incentives are justified for the host economies given the fact that this entails a transfer of resources from host countries to foreign firms 
reexamines the effects of government policies on market imperfections and foreign direct investment (FDI). It broadens and refines the analysis of the impact of government policies (Brewer, 1993).

A fraction of empirical research has also come out with the importance of openness to trade as well as regional and bilateral agreements to the attraction of FDI inflows. (Neumayer \& Spess, 2005) provide quantitative evidence that a higher number of bilateral investment treaties (BITs) raise the FDIs that flows to a developing country. (Büthe \& Milner, 2008) argue that international trade agreements (GATT and WTO) and preferential trade agreements (PTAs) reassure investors and increase investment. Studies like (Globerman \& Shapiro, 1999) find that Canada U.S. Free Trade Agreement (CUFTA) and North American Free Trade Agreement (NAFTA) increased both inward and outward FDI. (Blomström et al., 2003) separate the effects of regional trade agreements (RTA) along two dimensions, i.e., the indirect effect on FDI through trade liberalization and the direct effects from changes in investment rules connected with the regional trade agreements.

This study seeks to add to the existing literature on the determinants of FDI inflows in the country Ghana by empirically examining not only the already used macroeconomic variables in previous literature but also seeks to combine the governmental policies that is the selected investment incentives as well as regional and bilateral investment treaties. This helps gives a broader perspective as well as a comprehensive analysis on the factors affecting FDI inflows in Ghana. It also seeks to compare inflows of FDI between the 1990s and the 2000s as well as reasons for inflow or decline in attracting investors.

\section{Additional Determinants of Foreign Direct Investment}

\subsection{Bilateral Investment Treaties And Foreign Direct Investment}

It can be seen that over the past few years, world trade has been almost replaced by foreign direct investment. Since this is yielding to be a major source of funds especially for developing countries, the flow of FDI has grown at twice the pace more than worldwide trade. By the early 1990s, the sales of worldwide exports would be eclipsed by the sales of foreign affiliates of Multinational firms (Ali, Fiess, \& MacDonald, 2010; Habib \& Zurawicki, 2002). Gradually, in 2003, FDI was the largest component of the net resource flows to developing countries, and this is bound to remain the case for some time to come (Bartels, Napolitano, \& Tissi, 2014) Indeed, FDI inflows per unit of GDP are much higher in many developing countries than in developed ones (E. J. W. d. Asiedu, 2002). This led to the introduction of BITs and in light of its importance to FDI especially in developing countries like Ghana, there is a need to empirically study the relationship these two variables have and how one can adversely affect the other.

The appearance of the first Bilateral Investment Treaties (BITs) could be traced back to the late 1950s, others trace it back to the treaties of friendship, commerce and navigation. It was not until a century later that the first research was conducted by the UNCTAD and World Bank to access how effective BITs are in attracting foreign investment. Later there was an outburst of various literatures each espousing on uncovering the relationship and causal link between BITs and foreign investment, each work building on previous works of other researchers. Ghana, being a member of the Multilateral Investment Guarantee Agency of the World Bank, has over the years signed various investment treaties with many countries all over the world. Additionally, the Government of Ghana has entered into Bilateral Investment Promotion and Protection Agreements, as well as Double Taxation Agreements with a number of countries to further enhance the protection and security of the investment regime. One of Ghana's first agreement to sign was with its formal colonizer, The United Kingdom of Great Britain and North Ireland on $22^{\text {nd }}$ March 1989, the agreement entered into force in 1991. The Ghana- United Kingdom investment treaty was designed to create favorable conditions for greater investments by nationals and companies of one state in the territory of the other State. This led to further agreements being signed between the Republic of Ghana and the Kingdom of Netherlands, the Republic of China, the Swiss Confederation, Federal Republic of Germany, Republic of France and the Federation of Malaysia all between 1989 - 1997. It should be noted that some of these agreements have been signed but yet to be entered into force. 


\subsection{National Investment Policies and Foreign Direct Investment}

Ghana, like many developing African countries, is abundant in natural resources, deposits of mineral wealth, a good supply of agricultural land suitable for agricultural production, forest resources, marine and fresh water fish stocks, and a good potential for hydroelectricity generation. With an internal market of around 18.3 million, people and the potential of an extended market as trade barriers in West Africa are systematically being dismantled through integration of individual states into the Economic Community of West African States (ECOWAS), the natural assets collectively constitute an important attraction for inward FDI. Yet, during the 1980s, Ghana attracted are relatively negligible amount of FDI (Afriyie \& investment, 1998). This points to the fact that, although natural resources play an important role in FDI inflow, if Ghana is to attract FDI on the scale needed it must offer foreign investors new sources of competitive advantage rather than a reliance on natural resources alone. It is against this background I undertake this research to access other potential allies Ghana can uncover to improve FDI Inflows. The government of Ghana has provided a variety of investment incentives for foreign investors. These include tax holidays, capital allowances, locational incentives, customs duty exemptions and other inducements.

The general aim of investment incentives is to influence the locational decisions of investors and thus to reap the positive effects of foreign direct investment (FDI). Investment incentives may also be provided to shape the benefits from FDI by stimulating foreign affiliates to operate in desired ways. It also serves to direct them into regions or industries considered in need of investment. An example can be seen in investment incentives referred to as grants to locally based companies for investing in advanced technologies or to subsidies to foreign firms investing in the locality.

As part of investment incentives offered by the government of Ghana under the Ghana Investment Promotion Centre, also created was the Ghana Free Zones Board (GFZB) established on $31^{\text {st }}$ August, 1995 by an Act of Parliament the Free Zone Act, 1995 (Act 504) - to enable the establishment of free zones in Ghana for the promotion of economic development and also to provide for the regulation of activities in free zones and for related purposes. The implementation of the Programme actually commenced in September 1996.

The main objective of the Programme is the promotion of economic development through, attraction of Foreign Direct Investments; creation of employment opportunities, increasing foreign exchange earnings; provision of business opportunities for foreign and local investors to undertake joint venture, enhancement of technical and managerial skills/expertise of Ghanaians and also promotion of the transfer of Technology and diversification of exports. However, with the increasing pressures of globalization induced competitiveness, the locational advantages based on only the economic conditions may not be able to sustain their strength of attracting FDI. Possessing the principal determinants may not be sufficient for the host countries, as improving efficiency in international production becomes one of the major goals of FDI. This is made possible by the rising international division of labor and international production networks. Recently, studies have brought out the need for improving and sustaining locational advantages in the host countries by the active role played by the governments of the host countries. The focus therefore has now shifted to government policies in addition to economic conditions as a determinant of FDI.

In recent years, international investors have been aided by the growth of investment treaties. It serves as a binder between the host country to treat all foreign investors from the home country in ways that will protect their investments and that give them either parity with or advantages over domestic investors. The preambles of various literature on BITs state that the main focus of signing such treaties is to improve the inflow of FDI in host countries, and undoubtedly most government officials in developing countries perceive that notion thus serves as a motivation for them to engage in such agreements. But do these treaties fulfil that purpose and attract more FDI to developing countries that submit to the obligations of the BITs? This study seeks to find out exactly how the signing of these investment incentives have contributed to the growth and development of FDI inflows in the Republic of Ghana. 


\section{Methodology}

\subsection{Variables and Data Source}

The sources of data for this study are World Development Indicators of the World Bank (databank.worldbank.org), United Nations Conference on Trade and Development (UNCTAD) Investment Policy Review of Ghana and the Ghana Investment Promotions Centre Laws and Regulations, Executed and Ratified BITs between Ghana and other countries.

\subsection{Model Specification}

$$
F D I_{t}=\beta_{1}+\beta_{2} A T E_{t}+\beta_{3} W S W_{t}+\beta_{4} G D P_{t}+\beta_{5} R E E x R_{t}+\beta_{6} T I t+\beta_{7} B I T t+U_{t}
$$

Eq (1) shows the factors influencing FDI in Ghana. The independent variables used in this study are listed in Table 1. The dependent variable in the present study is (FDI) Inflow of Net Foreign Direct Investment. It is hypothesized that all the predicting variables will have a significant positive effect on the dependent variable.

Table 1: List of independent variables

\begin{tabular}{ll}
\hline Dependent Variable & Variable \\
\hline GDP Growth (Annual \%) & Gross Domestic Product \\
$\boldsymbol{W S W}$ & Waged and Salaried Workers \\
$\boldsymbol{A T E}$ & Access to electricity \\
$\boldsymbol{R E E R}$ & Real effective Exchange rate \\
$\boldsymbol{T I}$ & Tax Incentives \\
$\boldsymbol{B I T}$ & Bilateral Investment Treaties \\
$\boldsymbol{B}$ & Coefficients \\
\hline
\end{tabular}

The model is a time series estimated from the period 1989- 2018. It makes use of time series data spanning for thirty years. The impact of the economic fundamentals is estimated with variables such as the availability of infrastructure, cost of labor, gross domestic product and real exchange rate. These are all variables used by previous literatures in the determination factors affecting inflows of FDI in various regions. The impact of the selected national investment incentives as well as the bilateral agreements signed between Ghana and other countries are examined. We now discuss in detail the methodology adopted and variables selected with the above-specified model along with data source.

\subsection{Expected Relationships}

\subsubsection{Economic Fundamentals as determinants of FDI}

Overall economic policy helps in strengthening the fundamentals of the economy. There are various sources of literature that have analyzed and examined the determinants of FDI in various regions. Drawing on the vast literature on economic fundamentals, we employ the availability of infrastructure, cost of labor using the access to electricity and wage of salaried workers as a proxies respectively. Also used in this paper is the gross domestic product as well as the real exchange rate. Studies have found market variables, quality of human capital, macro-economic stability, financial health and infrastructure availability in the economy to have a positive impact while cost variables (e.g., labor cost, energy cost) are expected to be negatively related to FDI inflows (Welfens, 1994). The definitions of the above variables along with their expected signs as inferred from the literature and the sources of data are explained below;

1. Availability of infrastructure

It is perceived according to various papers that the higher the availability of infrastructure lower is the infrastructure costs and higher is the ability of the host country to attract FDI. However, different studies 
have used different measures to capture the availability of infrastructure. Some of the variables employed are land and property rents, index of infrastructure, and transportation costs among others. We use one variable here, that is, access to electricity available to the population to illustrate the availability of infrastructure, it being availability of electricity. Other literature employs the energy production (equivalent tonnes of coal per 1000 population). Due to lack of data for that we employ the other variable, availability of electricity to the population.

\section{Cost factors}

Factors that cause investment cost differentials across countries are categorized as Cost factors. These include cost of labor, cost of capital and infrastructure costs. Cost Factors may significantly influence the choice of an investment location for the resource seeking and efficiency-seeking FDI. To capture cost of labor and availability of skilled labor we use waged and salary rate of workers. This helps shed more light on the amount of monies foreign investors are expected to spend per worker as they employ and start business operations. It gives an estimated front on how to budget for the salaries of workers as well as the total number of people needed depending on the type of business being ventured into. We expect lower real wages of salaried workers in the host country to attract inward FDI. The real value for waged and salaried workers is employed in this model. This is calculated by the author by combining the nominal value of waged and salaried workers with the GDP deflator which was also manually calculated by the author and multiplied by 100 . This is done for the duration of thirty years, that is, from years 1989 to 2018 . The base year for the calculation was the year 2010 .

\section{Real Exchange Rate}

There is mixed evidence on the impact of depreciation of real exchange rate in the host country on FDI inflows. Foreign investors may gain or lose from a devalued exchange rate. They may gain due to larger buying power in host countries. Also, they can produce more cheaply and therefore export more easily. This may, therefore, attractresource seeking and efficiency-seeking FDI. However, foreign firms may not enter if they believe that depreciation may continue after they enter a country as this would imply costs to be too high to justify their investments (Treviño \& Mixon Jr, 2004). We expect devalued exchange rate to encourage inflow of FDI in the host countries, as this would reduce the cost of investment to the foreign firms.

\subsubsection{National FDI investment policies}

The National FDI policies that attract foreign investors into a host country have assumed greater importance in this liberalized regime. However, as observed by (Globerman \& Shapiro, 1999) it is quite cumbersome to statistically examine the impact of FDI-specific policies like incentives offered and removal of restrictions on the operations of foreign firms, since they are hard to isolate from other factors, "often because they are more implicit than explicit". Another of the difficulties in empirically examining the impact of these policies is the difficulty in quantifying these policies. Studies that have empirically tested for the impact of government policies on FDI flows are generally based on benchmark surveys at a point of time (E. J. W. d. Asiedu, 2002) or they observe the impact for a particular country over a period of time. There are two main categories of FDI incentives offered by developing countries to attract FDI inflows.

First are fiscal incentives, i.e., policies that are designed to reduce tax burden of a firm; and second is financial incentives, i.e., direct contributions to the firm from the government (including direct capital subsidies or subsidized loans). Fiscal incentives include tax concessions in the form of reduction of the standard corporate income-tax rate; tax holidays; accelerated depreciation allowances on capital taxes; exemption from import duties; and duty drawbacks on exports. Financial incentives include grants; subsidized loans and loan guarantees etc. This study focuses on the fiscal incentives offered particularly pertaining to tax incentives offered by host country. Tax Holidays; A zero score is allotted in period, if no tax holidays are declared. If tax holidays are declared for five or more years a score of two is allotted and if it is less than five years a score of one is allotted. The role of incentives in attracting FDI has been questioned on theoretical as well as empirical grounds as discussed earlier. The results with respect to impact of incentives offered by host countries to inward FDI are 
ambiguous in nature. Several studies with respect to incentives find that fiscal incentives do affect location decisions, especially for export oriented FDI, although other incentives seem to play a secondary role. However, fiscal incentives appear unimportant for FDI that is geared primarily towards the domestic market; instead such FDI appears more sensitive to the extent to which it will benefit from import protection. However, as discussed earlier, incentives must be viewed as a package and this requires a more nuanced view. The impact of incentives on inward FDI flows is expected to be positive.

\subsection{International FDI policy}

\subsubsection{Bilateral Investment Treaties}

In contrast to the number of trading agreements, there are very few investment agreements that exist. However, there has been a substantial increase in number of bilateral investment treaties (BITs) that have been signed and brought to force in the last two decades and particularly in the 1990s. Ghana is a member of the Multilateral Investment Guarantee Agency (MIGA) of the World Bank, which provides investment guarantees against noncommercial risks for investments in developing countries. Additionally, the Government of Ghana has entered into Bilateral Investment Promotion and Protection Agreements (IPPAs), as well as Double Taxation Agreements with a number of countries to further enhance the protection and security of the investment regime. An important characteristic of

BITs is a considerable uniformity in the broad principles underlying the agreements (Bende-Nabende, Ford, Santoso, \& Sen, 2003), coupled with numerous variations in the specific formulations employed. BITs generally recognize the effect of national law on FDI and accept the right of governments to regulate entry of FDI. The study examines empirically the impact of total number of BITs signed by a country in a particular year on FDI flows. Many BITs have been signed between the government of Ghana and other countries but just a few have been ratified and enforced. For the purpose of study and data acquisition, the number of treaties signed, regardless of being ratified or not, were used in the data collected.

\section{Results}

In order to estimate the impact of economic fundamentals, national and international FDI policy on FDI inflows, the paper employs regression analysis making use of time series data. Where FDI is the dependent variable and access to electricity, waged and salaried workers, gross domestic product, real exchange rate, tax incentives and bilateral investment treaties are independent variables.

Table 2: Summary of Variables

\begin{tabular}{|c|c|c|c|c|c|c|}
\hline Variable & I & Obs & Mean & Std. Dev. & Min & $\operatorname{Max}$ \\
\hline year & & 30 & 2003.5 & 8.803408 & 1989 & 2018 \\
\hline accesstoel y & । & 30 & 45.65679 & 22.04004 & 0 & 79.3 \\
\hline realeffec 20 & I & 30 & 105.2392 & 33.08016 & 0 & 161.5889 \\
\hline taxincenti s & I & 30 & 1.866667 & .3457459 & 1 & 2 \\
\hline bilaterali s & I & 30 & .7333333 & 1.25762 & 0 & 5 \\
\hline \multicolumn{7}{|c|}{ 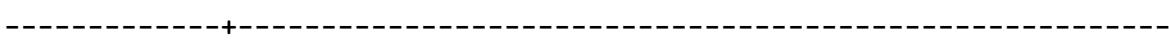 } \\
\hline wagedandsa e & I & 30 & 27.44922 & 13.40292 & 0 & 53.33306 \\
\hline fdiinflows s & 1 & 29 & $1.20 e+09$ & $1.20 e+09$ & $3.03 e+07$ & $3.15 e+09$ \\
\hline gdpgrowtha l & I & 30 & 5.219921 & 2.593947 & 0 & 14.04712 \\
\hline
\end{tabular}

The summary of the variables in the Hypothesized models are presented in Table 1. It shows the central tendencies of the variables presented in the number of total observations employed in this theorized model, the averages of the various variables, their respective standard deviation errors, the minimum observation as well as the maximum observations. 


\subsection{Correlation Matrix}

The pairwise correlation in table 3 shows the number of observations that were used in the correlation.

Table 3 Correlation Matrix

(obs=29)

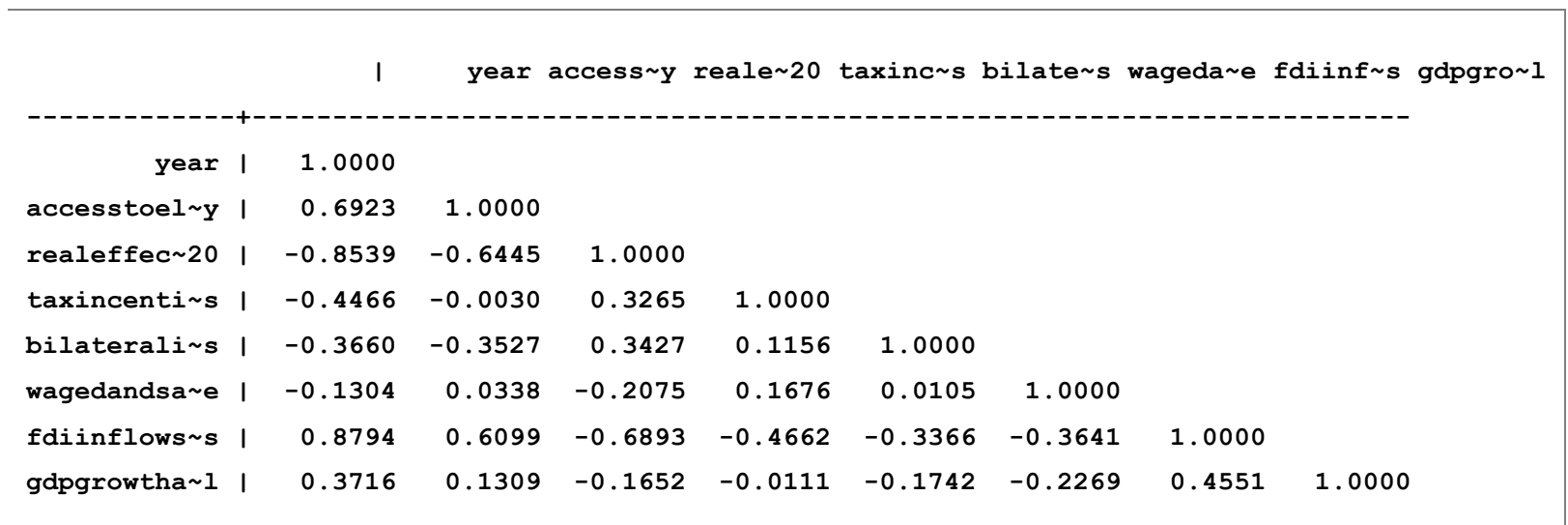

The table below reflects the Pearson coefficient value for each variable, the significance value and the sample size in the data set. In this data set we have no missing values therefore all correlations are based on all 29 observations. In principle correlation between any variable and itself is always 1. Correlation of a construct against another predicting variable in principle should not be more than 0.7 to avoid the problem of multicollinearity amongst the predicting constructs. In the same regard a predicting variable in theory should be predictive of the dependent variable at least 0.3 but preferably 0.7 and above to indicate a good fit of the model. The output between real effective exchange rate and access to electricity indicate a good model fit as predictors with their correlation not indicating a likelihood of multicollinearity problem, as well as real effective exchange rate and FDI inflows which is the dependent variable employed in the model. However, the output reflects that there is an inverse correlation between some of the constructs. This however is possible and acceptable in theory and principle.

\subsection{Regression Analysis}

Table 4 Regression Analysis

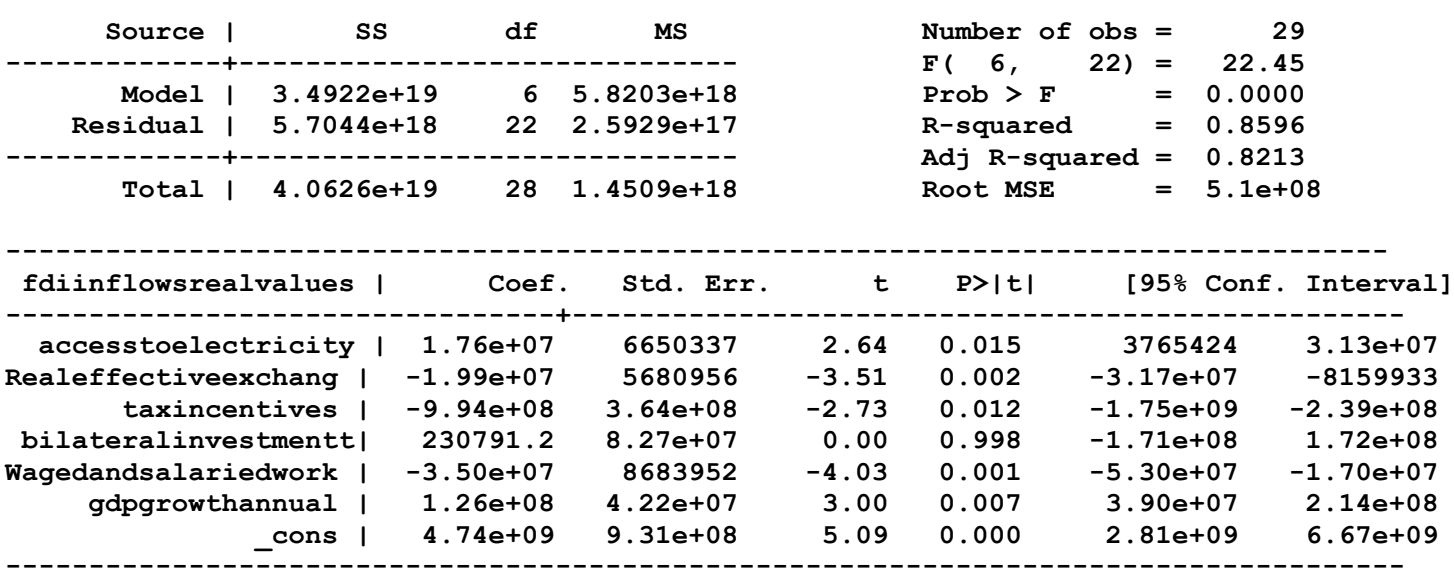

The times series data employed here with the data series spanning from 1989 to 2018 covering a period of 30 years. The R- Squared for the model is estimated at $85.96 \%$ and adjusted R-squared $82.13 \%$. All source of 
funds has a positive effect on inflows of foreign direct investment with the exception of bilateral investment treaties.

Wage of salaried workers are found to be statistically significant from results adhered from the model. As employment decreases, the level of wage cost in a particular country would also be drastically affected. Inexpensive labor force is decisive in stimulating and attracting FDI inflows in a particular country. Hence this would attract more FDI inflows as some investors and foreign firms would prefer investing in a country which has a relatively low wage cost. Real effective exchange rate also has a statistically significant effect on FDI inflows in Ghana with a t- value of -3.51 which is above the accepted critical t- value of 2.00 which makes economic sense.

The results are consistent with the proposition that a diminished currency value is associated with greater FDI inflows. This is because a depreciated currency value would lead to higher relative wealth position of foreign investors and hence lower the relative cost of capital. This allows foreign investors to make a significantly larger investment in terms of the domestic currency. A long-run negative semi-elasticity of greater than one is found in all models. The results support the findings of (Ang, 2008; Azrak \& Wynne, 1995).

The Adjusted R-squared of 0.8213 indicates that the model explains $82 \%$ of the extent to which a change in the annual growth of GDP of Ghana can influence a change in its inflows of FDI. The evidence also points to the importance of developing the infrastructure base, a result that conforms to the general consensus see (E. J. W. d. Asiedu, 2002; Deichmann, Karidis, \& Sayek, 2003). From the table, the analysis suggests that investors are attracted to a higher GDP growth rates in Ghana.

Specifically, the results indicate an absolute t- value of 3.00 which signifies a higher critical t-value of 2.00 . Indicating that, a $1 \%$ increase in gross domestic product will lead to about $0.99 \%$ increase in inward FDI. The evidence suggests that strong economic growth remains a necessary condition for Ghana to attract FDI inflows. The results are in line with the general findings of the literature, including (Billington, 1999; Choi, 2003; Wang \& Swain, 1995), which have consistently found a positive role of GDP growth rate. The provision of infrastructural support could raise the productivity of capital, and expand the overall resource availability by increasing output.

FDI inflows react positively to tax incentives or tax-free holidays. With a t-value of 2.73 which is above the critical value of 2.00. There is an inverse relationship that exists between inflows of FDI and tax incentives and national policies offered by a country. The results are in line with the argument that increasing the amount of tax incentives in Ghana is an effective policy instrument to boost inward FDI.

Similar results are also obtained by (Billington, 1999; Choi, 2003; Fedderke \& Romm, 2006; Wang \& Swain, 1995) Various studies show that incentives play a minor role in attracting FDI once the impact of economic fundamentals are controlled for. The variable bilateral investment treaties had a t- value 0.00 according to the model indicating its inability to have an effect on FDI inflows in Ghana.

\subsection{Heteroskedastic Test}

The Breusch- Pagan test for heteroskedasticity was tested using the fitted values of the model. It was found to have a constant variance and variables fit values of inflows of FDI. The chi square value was not significant at 0.48 with a $p$-value of $p<0.4884$ which is less than the appropriate threshold therefore rejecting the alternative hypothesis of heteroskedasticity and homoscedasticity assumed. 
Table 5 Outreg of Coefficient estimates

\begin{tabular}{|c|c|}
\hline Fdirealvalues & \\
\hline accesstoelectricity & $\begin{array}{c}17,557,379.703 \\
(2.64) \star\end{array}$ \\
\hline realeffectiveexchangerateindex 20 & $\begin{array}{c}-19,941,514.816 \\
(3.51) \star \star\end{array}$ \\
\hline taxincentives & $\begin{array}{c}-994,037,142.049 \\
(2.73)^{\star}\end{array}$ \\
\hline bilateralinvestmenttreaties & $\begin{array}{c}230,791.178 \\
(0.00)\end{array}$ \\
\hline wagedandsalariedworkersrealvalue & $\begin{array}{c}-35,016,892.230 \\
(4.03) \star \star\end{array}$ \\
\hline gdpgrowthannual & $\begin{array}{c}126,473,497.557 \\
(3.00) \star \star\end{array}$ \\
\hline _cons & $\begin{array}{c}4740898990.257 \\
(5.09) \star \star\end{array}$ \\
\hline R2 & 0.86 \\
\hline $\mathbf{N}$ & 29 \\
\hline
\end{tabular}

From the table above, FDI net inflows is the dependent variables with the other variables listed below as the independent variables. The number of observations is 29 although a time series of 30 years was employed. Waged and Salaried workers has the highest $t$ value of 4.03 with two asterisks indicating its $p$ value greater than 0.01 . This is followed by Real effective exchange rate and GDP annual growth percentage with $t$ values as 3.51 and 3.00 respectively with a $\mathrm{p}$ value of $\mathrm{p}<0.01$ significance levels. This gives a general tabulated summary of results of the regression analysis conducted.

Table 6 Chou- Test: To Test Structural Break

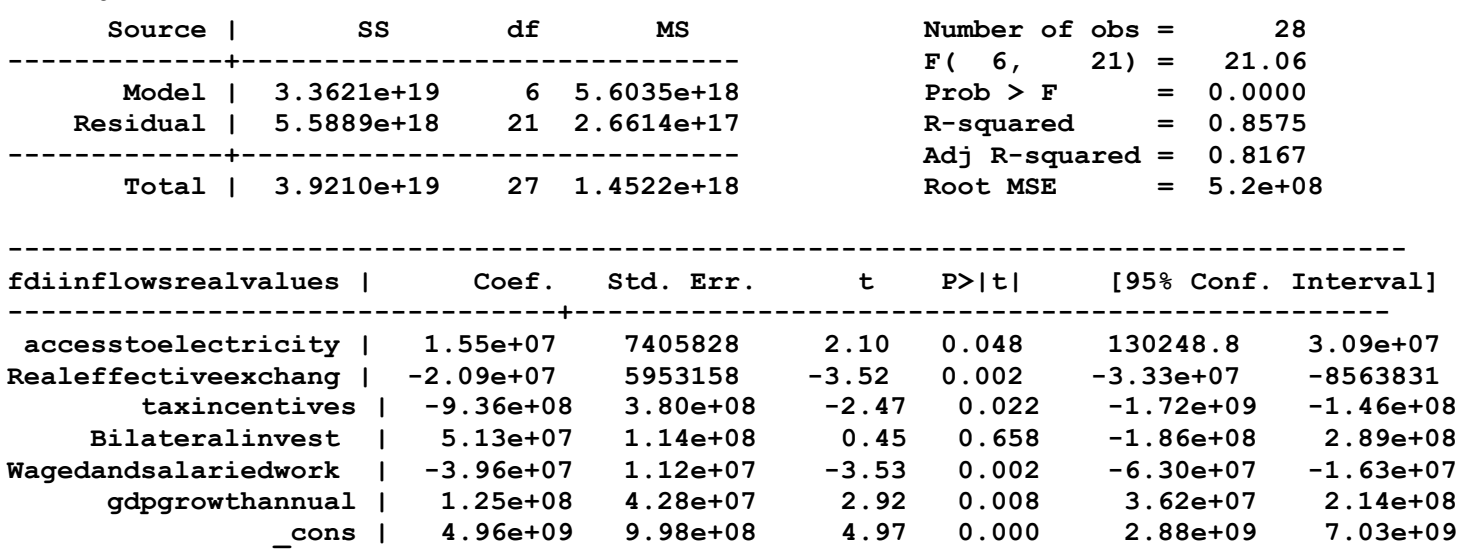

The table above shows the structural break of inflows of FDI as well as other variables for the years greater than or equal to 1990; 1990 inclusive. It can be observed that the in comparison to the other regression analysis described in table 3, the number of observations is 28 and the R-Squared is $85.75 \%$ and Adjusted R-Square as $81.67 \%$, the previous analysis recorded its R-Squared at $85.96 \%$ and Adjusted R-Square at $82.13 \%$. This indicates that within the years after 1989, FDI inflows in Ghana appreciated according to this model. Looking at the independent variables also, waged and salaried workers, real effective exchange rate, total annual gross domestic product, access to electricity and tax incentives still remained significant with -3.53, -3.52, 2.92, 2.10 and $-2.47 \mathrm{t}$ - values at a significant level of 2.00. Waged and salaried workers as well as Tax incentives and real effective exchange rate show an inverse relationship between it and FDI inflows, indicating that with the growth of one lead to an increase in the other. This reflects the same results as that of the previous regression run taking the significance of variables into consideration. Bilateral Investment Treaties however shows an insignificant value of 0.45 , although this is a higher value as compared to the first regression analysis run. During past times in Ghana, the launching of the Economic Recovery Program in 1983 sought to arrest the general decline; that is when many determinants of FDI was falling behind, leading to investors pulling away from Ghana. From 1984 onwards, there was a turn-around in the economy, with growth averaging 5\% per annum up to 1991. Indeed, by the mid-1980s the economy could be described as having been stabilized. The threats to political stability were 
also brought under control. An Investment Code was promulgated in 1985, aimed at establishing an enabling environment, especially for foreign direct investment. The new policy framework, together with a reasonable degree of political stability, led to a renewal of FDI flows, especially in the mining sector, by the late 1980s. The Structural Adjustment Programme (SAP) loans to the sector, with Ashanti Goldfields Company (AGC) the principal beneficiary. Evidence shows that government policy initiatives under the ERP/SAP, especially the revision of the Investment Code, were partly responsible for the increased FDI flows in the mining sector (Tsikata,1995). Gold has now taken the place of cocoa as the country's 3rd largest foreign-exchange earner.

By 1992, the pace of economic growth began to slacken, owing to a huge budgetary deficit therefore in a bid to restore the trend, remedial policies were initiated to create an enabling environment for medium- and long-term growth. More specifically, in its Ghana: Vision 2020 (1996-2000). The urgency of the government's FDI agenda led to a re-assessment of the 1985 Code, embedded in the 1994 Investment Act which led to the set up the Ghana Investment Promotion Centre (GIPC) as an aggressive promotion body. So far, the Centre has recorded modest success. Up to 1998, it had registered 735 companies, 506 are them joint ventures, involving total investment outlays of US $\$ 989$ million, and 229 wholly foreign-owned projects. The investments are expected to generate a total employment of around 43,000 (GIPC1998). 1993-1996 it was a period of significant, but oscillatory, inflows which peaked in 1994 at $\$ 233$ million, fell by more than 50\% (\$107) million in 1995, and rose again to $\$ 120$ million in 1996. The period average was slightly above \$146 million. There were indications (Ghana Investment Promotion Centre and the Minerals Commission, March, 1998) that the upward trend might continue. Thereafter FDI increased substantially, reaching a peak of \$233 million in 1994.

Figure 1 Scatter diagram showing FDI net inflows if year is $\geq 1990$

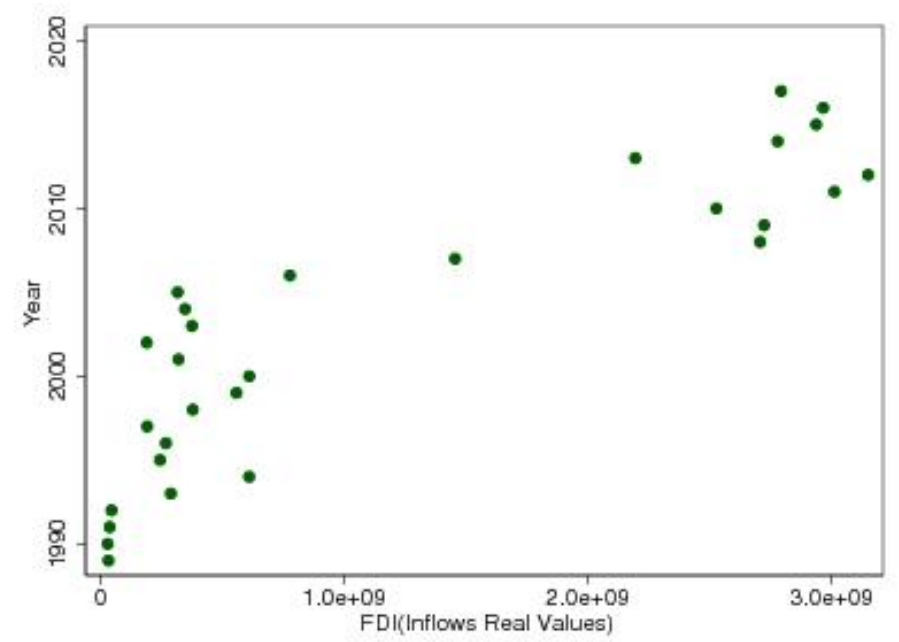

Figure 2 Scatter diagram showing Access to electricity if year is $\geq 1990$

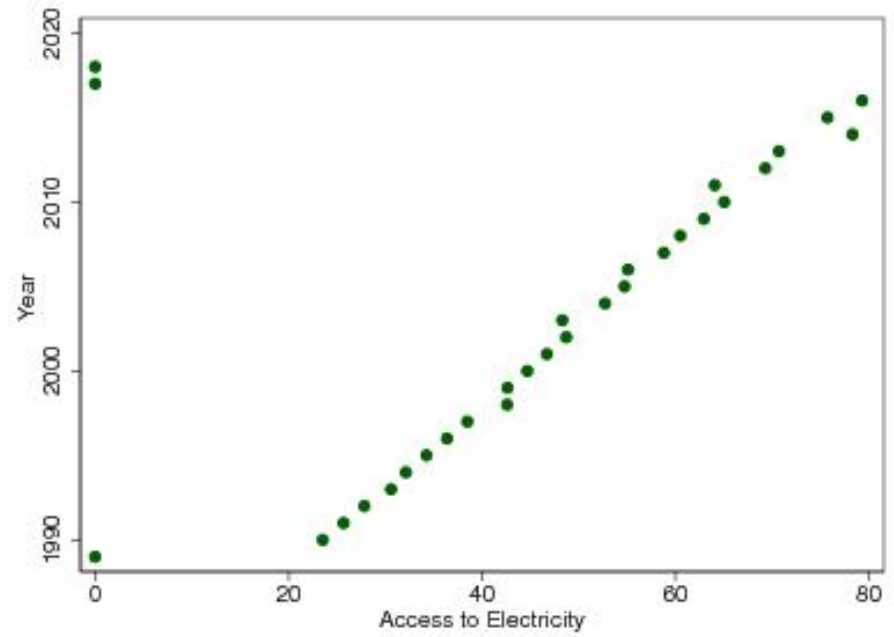


Figure 3 Scatter diagram showing Real Effective Exchange Rate Index if year is $\geq 1990$

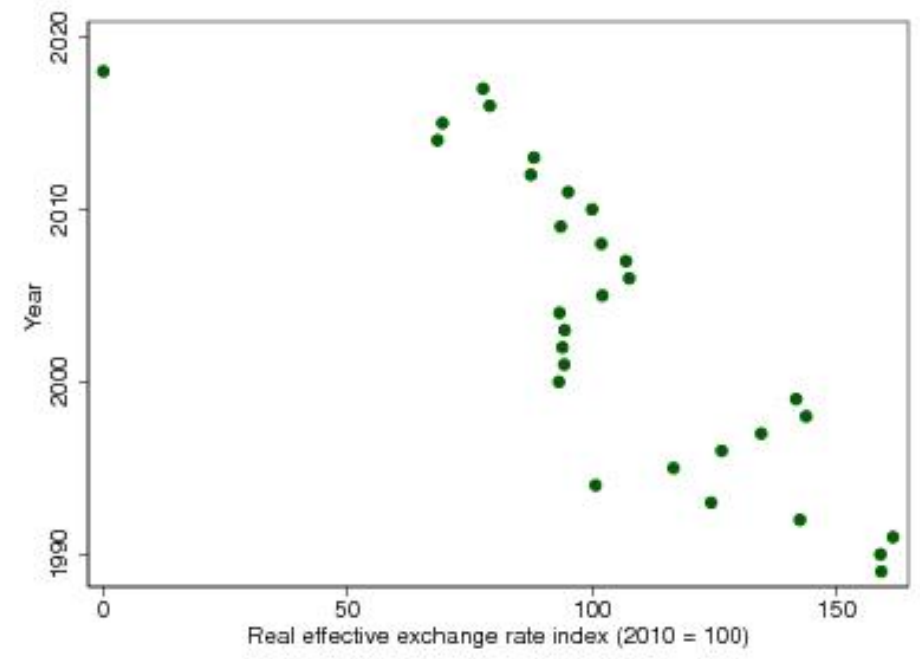

Figure 4 Scatter diagram showing Tax Incentives if year is $\geq 1990$

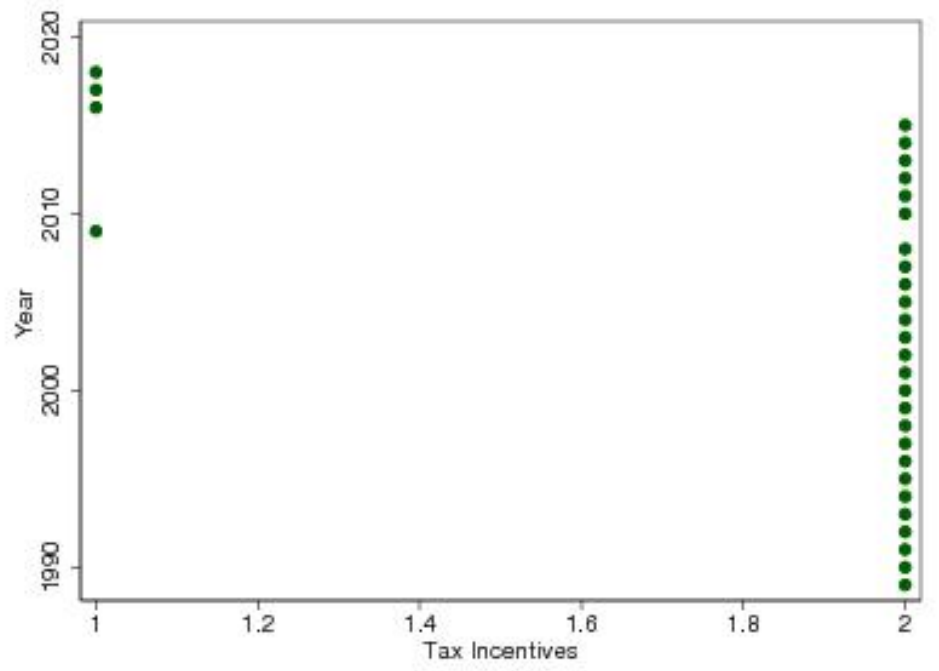

Figure 5 Scatter diagram showing Bilateral Investment Treaties if year is $\geq 1990$

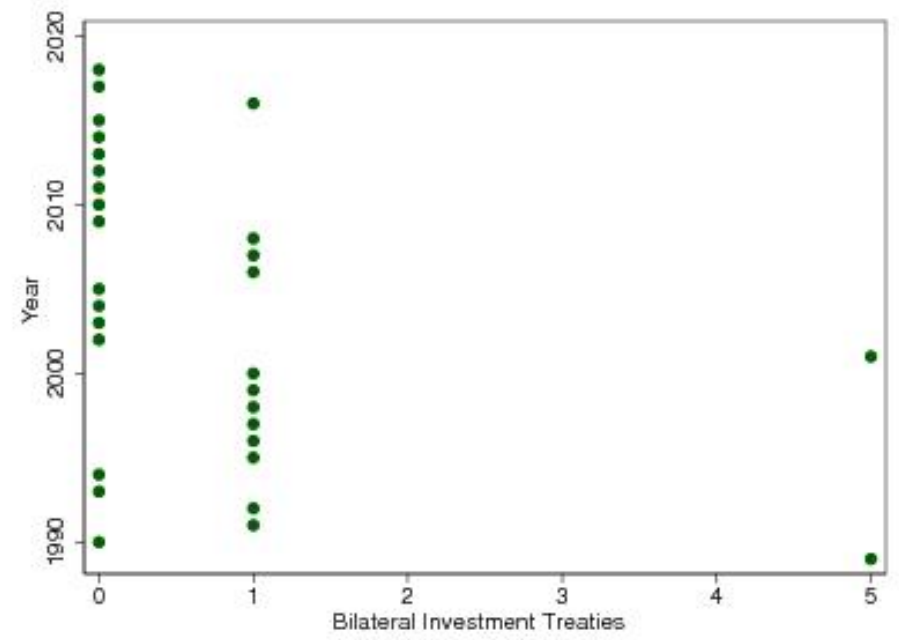


Figure 6 Scatter diagram showing GDP annual growth \% if year is $\geq 1990$

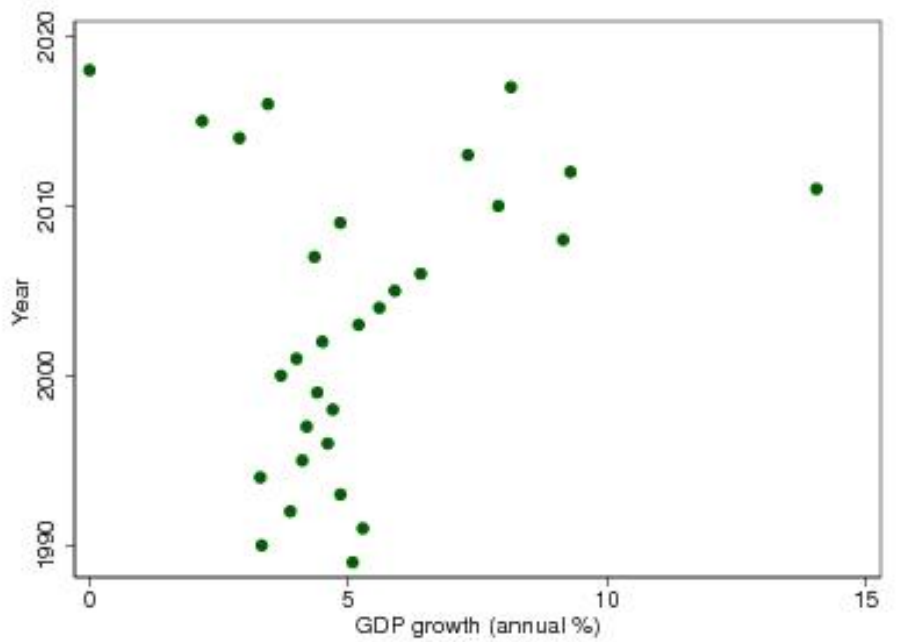

Table7: Chou test to test for structural break

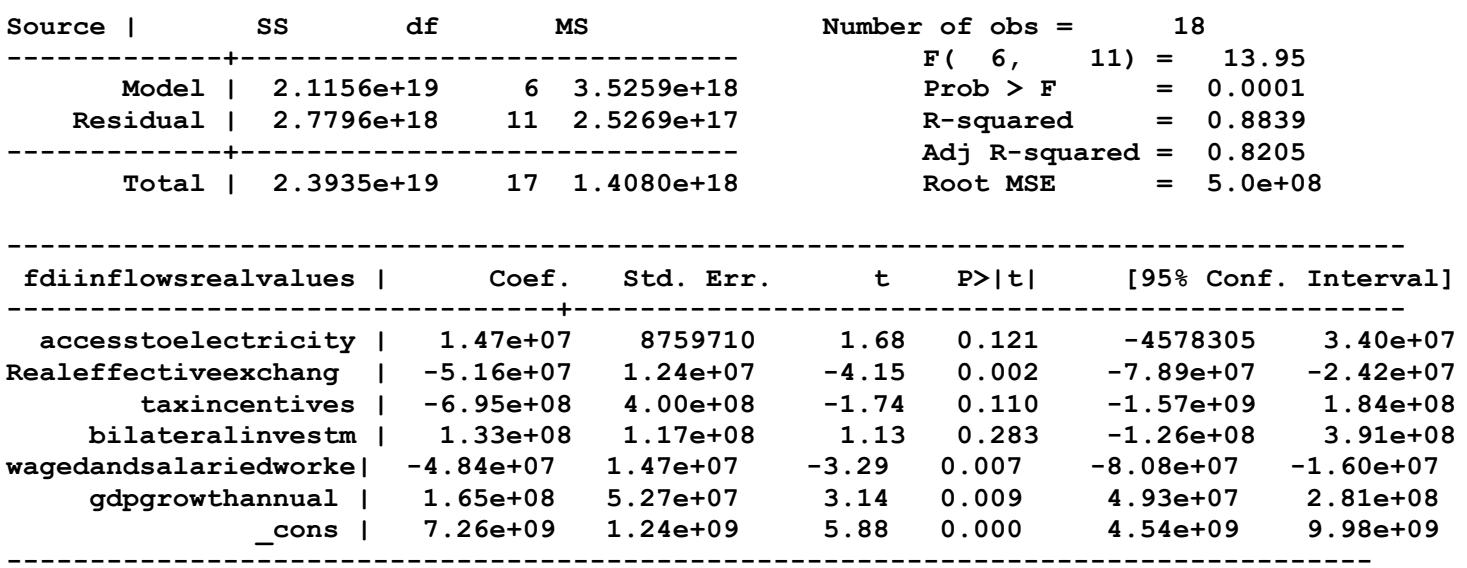

The table above shows the period within and after 2000 . Here it is seen that the number of observations as 18 , the R- Squared value is seen to have increased from $85 \%$ to $88 \%$ and the Adjusted R-Square of $82 \%$. It can be observed that though it records the highest of the adjusted and $r$ square value, some variables that are significant from the year 1990 such as Access to electricity is considered insignificant according to the model. However, real effective exchange rate, waged of salaried workers, and annual gross domestic product remain significant in both models. It can be observed that real effective exchange rate and waged and salaried workers show a positive inverse relationship with t- values of -4.15 and -3.29 respectively. It can be also be observed that tax incentives shows a weak inverse relationship with $t$ value of -1.74 . As compared to the previous analysis, tax incentives though having an inverse relationship does not have a significant $t$ value in this analysis. Real effective exchange rate recorded the highest t- value signifying the importance of the exchange rate which reports a t- value of 4.15 , which is above the $t$ value of 2.00 .

Between 2000 and 2014, the total inward FDI flow to Ghana amounted to more than US\$ 27 billion. There was a stable inflow of FDI from 2000 to 2005 with the lowest value of investments in 2002 at US\$ 70 million. Numerous reasons led to the low inflow of FDI to Ghana throughout this time period. For instance, in 2001, the Government of Ghana opted for the Highly Indebted Poor Countries (HIPC) Initiative to persuade its development partners to cancel Ghana's debt in return for solutions to the country's socio-economic problems that was affecting all aspects of Ghana's development. During this period, Ghana's development partners suspended their assistance in order to allow the country to properly reorganize their affairs. This situation contributed to the discouragement of investments by foreign businesses as a country in the HIPC initiative will have its image marred and will deter both private and public investments. The flows FDI then fluctuated between 2006 and 2010 but increased rapidly by more than fivefold at a high of US\$ 7.7 billion in 2011 and after that, 
flows declined. The decline in growth in FDI flows after 2011 to 2014 was partly caused by the political uncertainty beleaguering every election year in Ghana as it was in the past election years (that is election years 2000, 2004 and 2008).

During every election year, foreign investment always shows a downward trend due to foreign investors' lack of confidence in African politics as a whole and its numerous uncertainties of the outcome. This usually happens months leading up to elections and six months after that as was experienced during the 2012 general elections in Ghana which resulted in a lengthy court dispute over the result which led to an eight-month court case copulated with the energy crisis resulting to most potential and existing investors' lukewarm investment flow. Another factor that contributed to the slow progress in attracting FDI during this period was the devaluation of the Cedi resulting from ongoing trade and current account imbalances. In 2013, the Ghanaian Cedi dropped 15\% against the Dollar and although the Central Bank of Ghana in 2014 implemented a string of foreign exchange controls, it had little effect to stop the slide which increased inflation and leading the International Monetary Fund (IMF) to project a current account deficit of $9.1 \%$ in the same year (Oxford Business Group, 2014).

Figure 7 Sunflower diagram showing FDI net inflows if year $\geq 2000$

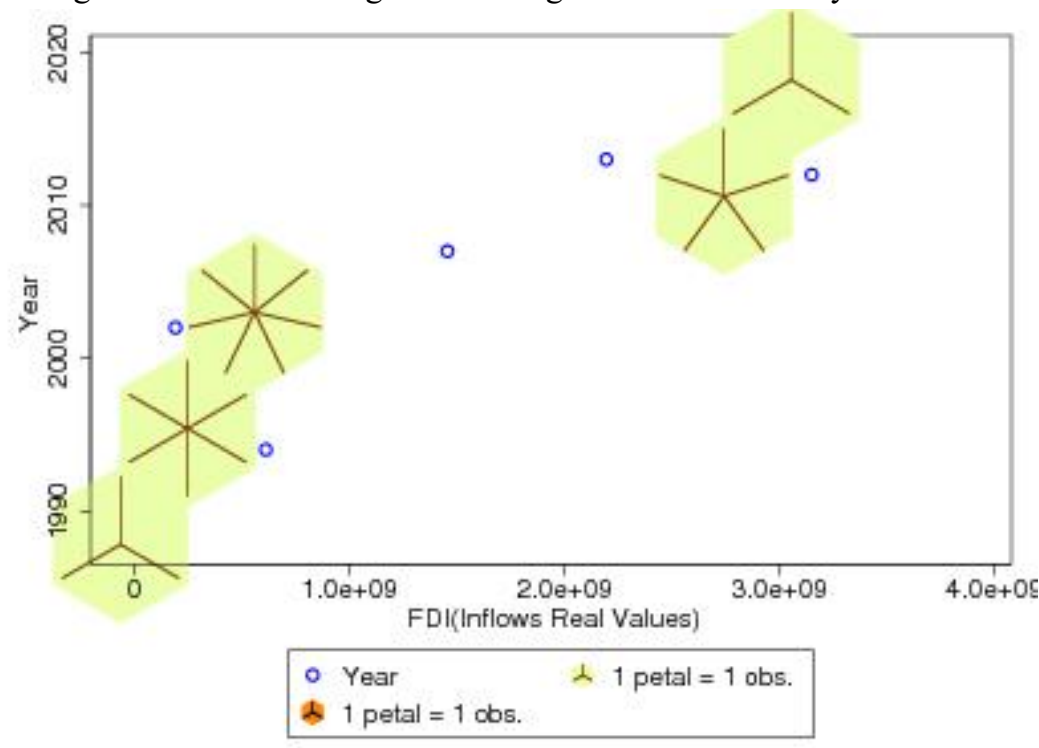

Figure 8 Sunflower diagram showing Access to electricity if year $\geq 2000$

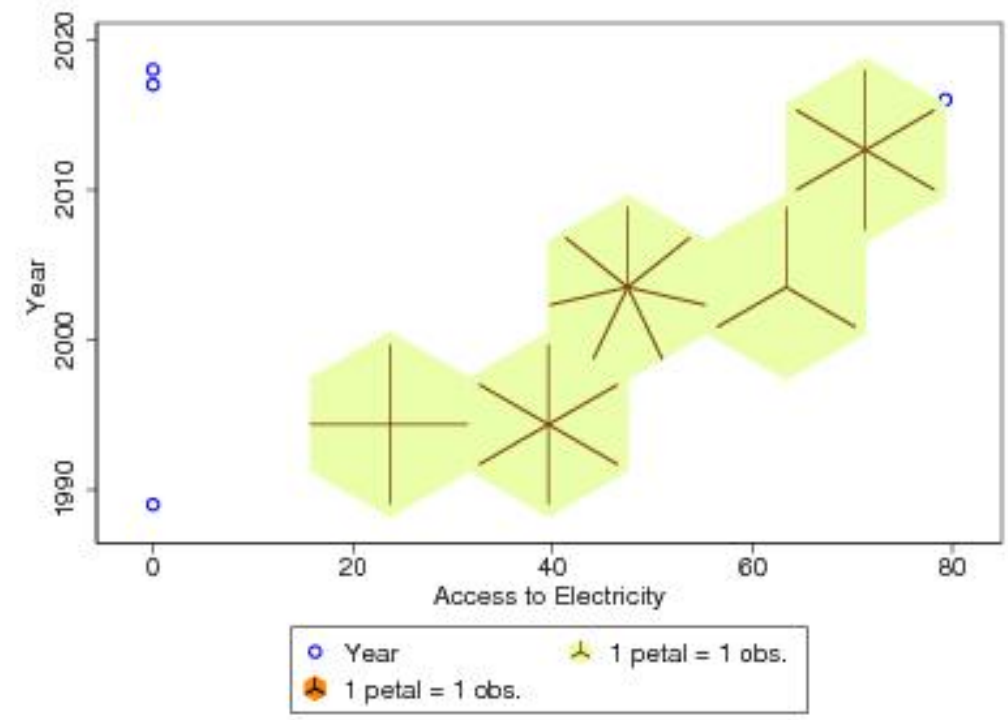


Figure 9 Sunflower diagram showing Real effective Exchange Rate Index if year $\geq 2000$

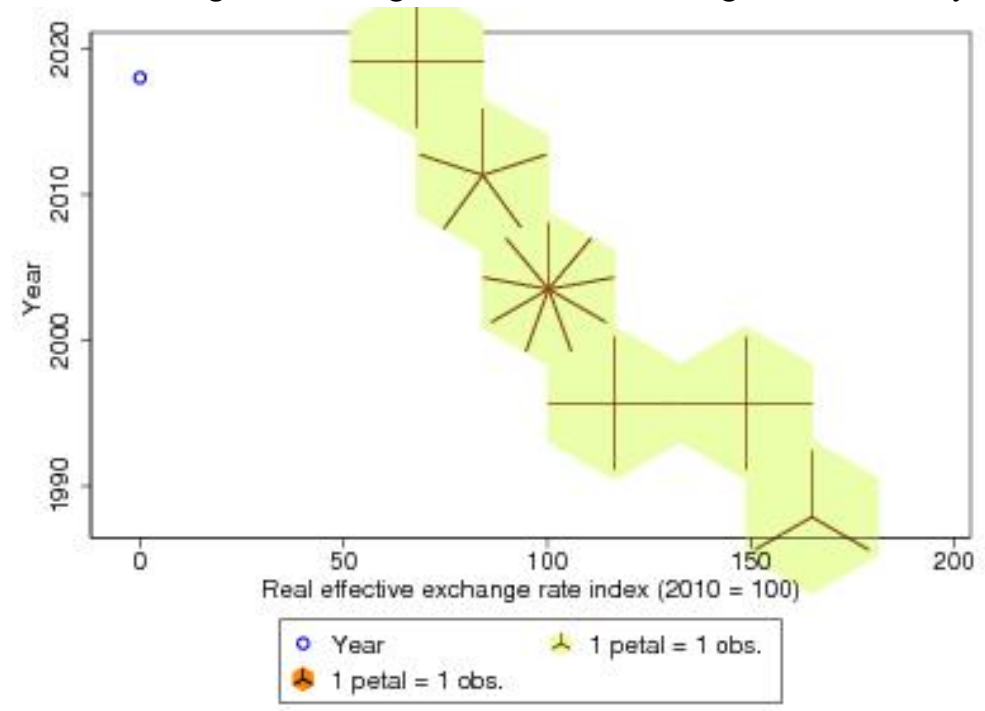

Figure 10 Sunflower diagram showing Tax Incentives if year $\geq 2000$

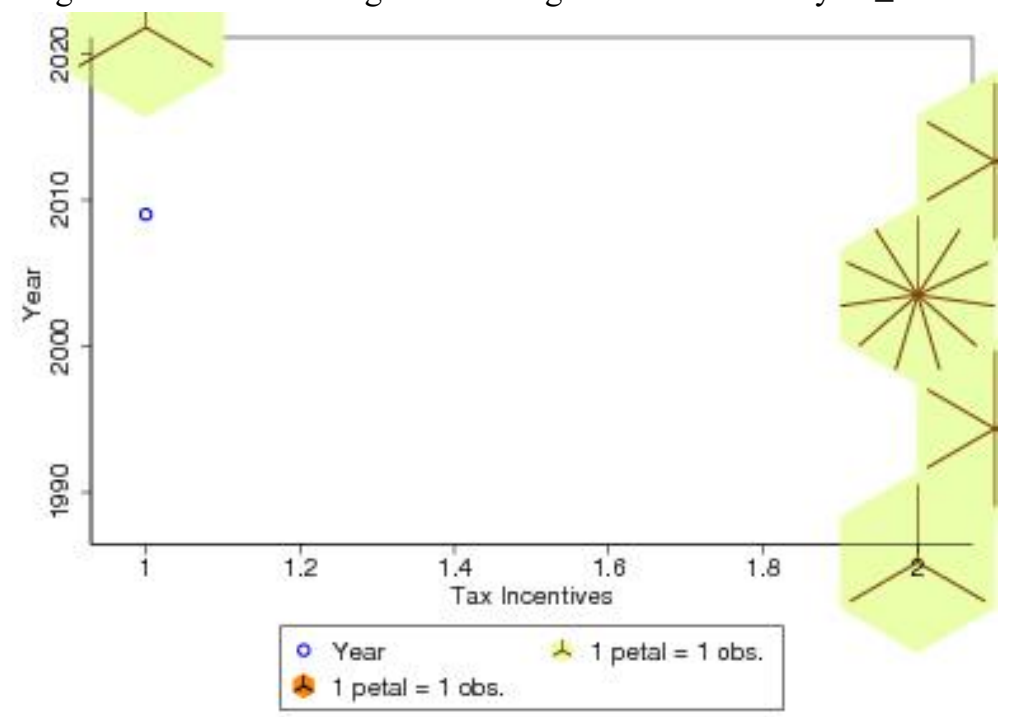

Figure 11 Sunflower diagram showing Bilateral Investment Treaties if year $\geq 2000$

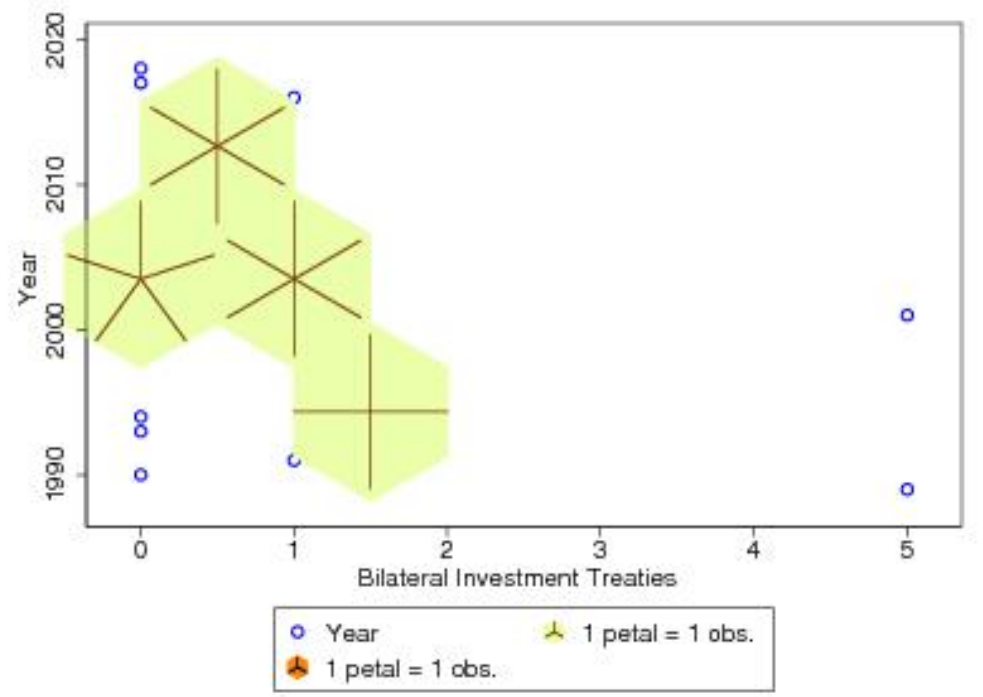


Figure12 Sunflower diagram showing Wage and Salaried Workers total \% if year $\geq 2000$

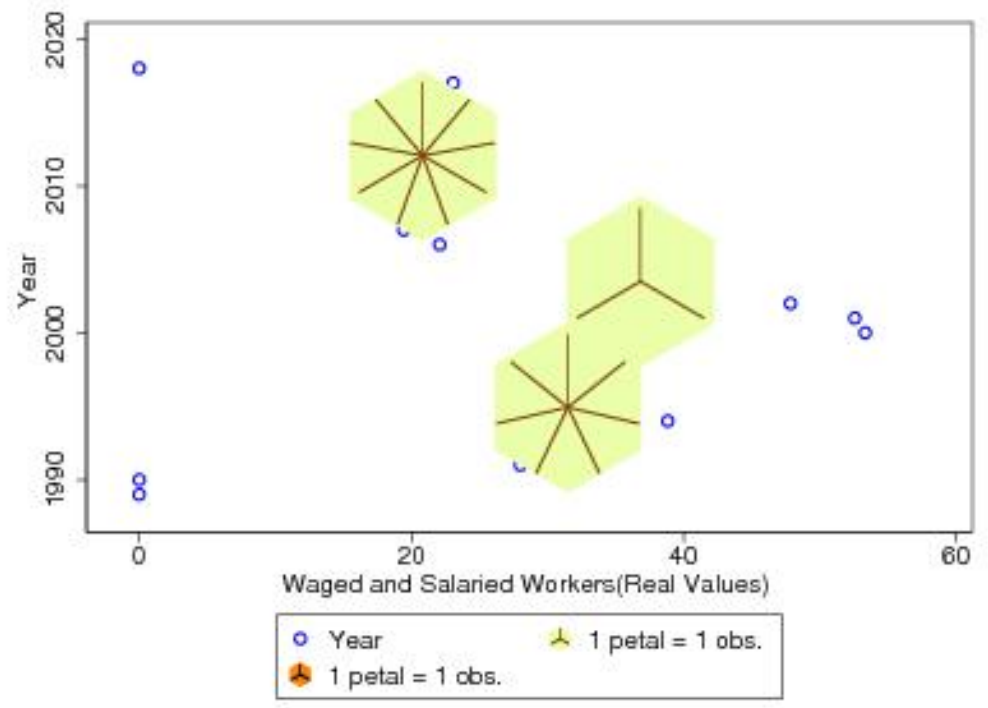

Figure 13 Sunflower diagram showing GDP growth annual \% if year $\geq 2000$

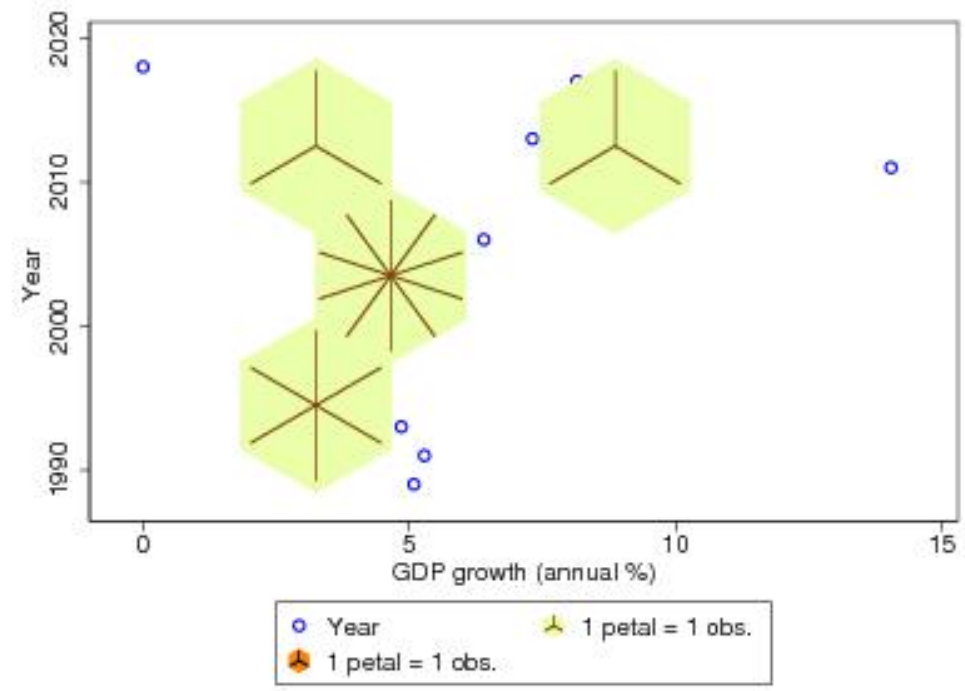

\section{Conclusions and Remarks}

The paper sought to provide a comprehensive analysis of determinants of FDI inflows in Ghana. Most papers or existing literature focused mostly on the economic variables as factors affecting the inflows of FDI in Ghana. Though this is true to some extent, as time evolved other factors have been included in the explanation process of inward FDI in many countries. Thus, the contribution of this paper to shed more light on the new policies added and considered when discussing the determinants of FDI in a region. Another contribution of this paper is the structural break performed for the years greater than or equal to 1990 and years greater than or equal to 2000 . It is observed that inflows of FDI vary during the various periods as well as reasons leading to the decline or increase in FDI. This helps policy makers in devising strategic procedures to avoid such declines and also adapt measures to if not maintain but all upgrade measures to attract more foreign investors. It can also be observed that though the Republic of Ghana has signed many bilateral trade agreements with other countries, just a handful have been ratified, thus reflecting a low percentage of BITs as a contributing factor of FDI. Though it cannot be generally concluded that signing more BITs will lead to an increment of FDI inflows, it is an avenue worth tapping into for potential. National Policies as factors determining FDI also from the model proved to play a significant role in attracting FDI into Ghana, though limited to some sectors and neglecting others. It lastly 
emphasizes the importance of the Free zones policy introduced by the Government of Ghana as a means of attracting foreign direct investment

\section{Acknowledgement}

This research is supported by the Major Program of National Social Science Foundation of China, No. 15ZDA053.

\section{References}

Afriyie, K. J. G., trade, \& investment, f. d. (1998). Foreign direct investment in Ghana's emerging market economy. 217-236.

Alfaro, L., Chanda, A., Kalemli-Ozcan, S., \& Sayek, S. J. J. o. i. e. (2004). FDI and economic growth: the role of local financial markets. 64(1), 89-112.

Ali, F. A., Fiess, N., \& MacDonald, R. J. O. e. r. (2010). Do institutions matter for foreign direct investment? , 21(2), 201-219.

Ang, J. B. J. J. o. p. m. (2008). Determinants of foreign direct investment in Malaysia. 30(1), 185-189.

Asiedu, E. J. W. d. (2002). On the determinants of foreign direct investment to developing countries: is Africa different? , 30(1), 107-119.

Asiedu, E. J. W. e. (2006). Foreign direct investment in Africa: The role of natural resources, market size, government policy, institutions and political instability. 29(1), 63-77.

Azrak, P., \& Wynne, K. J. J. o. P. M. (1995). Protectionism and Japanese direct investment in the United States. 17(3), 293-305.

Bartels, F. L., Napolitano, F., \& Tissi, N. E. J. I. B. R. (2014). FDI in Sub-Saharan Africa: A longitudinal perspective on location-specific factors (2003-2010). 23(3), 516-529.

Bende-Nabende, A., Ford, J., Santoso, B., \& Sen, S. J. A. E. L. (2003). The interaction between FDI, output and the spillover variables: co-integration and VAR analyses for APEC, 1965-1999. 10(3), 165-172.

Billington, N. J. A. e. (1999). The location of foreign direct investment: an empirical analysis. 31(1), 65-76.

Blomström, M., Kokko, A., \& Mucchielli, J.-L. (2003). The economics of foreign direct investment incentives. In Foreign direct investment in the real and financial sector of industrial countries (pp. 37-60): Springer.

Brewer, T. L. J. J. o. I. B. S. (1993). Government policies, market imperfections, and foreign direct investment. 24(1), 101-120.

Büthe, T., \& Milner, H. V. J. A. j. o. p. s. (2008). The politics of foreign direct investment into developing countries: increasing FDI through international trade agreements? , 52(4), 741-762.

Choi, C. J. J. o. P. M. (2003). Does the Internet stimulate inward foreign direct investment? , 25(4), 319-326.

Contractor, F. (1991). Government policies toward foreign investment: an empirical investigation of the link between national policies and FDI flows. Paper presented at the Annual Meeting of the Academy of International Business, Miami, FL.

Deichmann, J., Karidis, S., \& Sayek, S. J. A. E. (2003). Foreign direct investment in Turkey: regional determinants. 35(16), 1767-1778.

Driffield, N., \& Taylor, K. J. O. R. o. E. P. (2000). FDI and the labour market: a review of the evidence and policy implications. 16(3), 90-103.

Dunning, J., \& Narula, R. (2003). Foreign direct investment and governments: catalysts for economic restructuring: Routledge.

Fedderke, J. W., \& Romm, A. T. J. E. M. (2006). Growth impact and determinants of foreign direct investment into South Africa, 1956-2003. 23(5), 738-760.

Globerman, S., \& Shapiro, D. M. J. J. o. I. B. S. (1999). The impact of government policies on foreign direct investment: The Canadian experience. 30(3), 513-532.

Grubert, H., \& Mutti, J. (1991). Financial flows versus capital spending: alternative measures of US-Canadian investment and trade in the analysis of taxes. In International Economic Transactions: Issues in Measurement and Empirical Research (pp. 293-320): University of Chicago Press.

Habib, M., \& Zurawicki, L. J. J. o. i. b. s. (2002). Corruption and foreign direct investment. 33(2), 291-307.

Hailu, Z. A. J. I. J. o. e., \& Finance. (2010). Impact of foreign direct investment on trade of African countries. 2(3), 122-133.

Hoekman, B., \& Saggi, K. J. J. o. E. I. (2000). Assessing the case for extending WTO disciplines on investmentrelated policies. 629-653.

Kumar, N., \& Pradhan, J. P. J. R. D. P. (2002). FDI, externalities and economic growth in developing countries: Some empirical explorations and implications for WTO negotiations on investment. (27).

Loree, D. W., \& Guisinger, S. E. J. J. o. I. B. S. (1995). Policy and non-policy determinants of US equity foreign 
direct investment. 26(2), 281-299.

Neumayer, E., \& Spess, L. J. W. d. (2005). Do bilateral investment treaties increase foreign direct investment to developing countries? , 33(10), 1567-1585.

Nunnenkamp, P. (2002). Determinants of FDI in developing countries: has globalization changed the rules of the game? Retrieved from

Onyeiwu, S., \& Shrestha, H. J. J. o. D. S. (2004). Determinants of foreign direct investment in Africa. 20(1-2), 89-106.

Review, U. J. F. T. (1996). World Investment Report 1996: Investment, Trade and International Policy Arrangements. 31(3), 85-109.

Sekkat, K., \& Veganzones-Varoudakis, M. A. J. R. o. D. E. (2007). Openness, investment climate, and FDI in developing countries. 11(4), 607-620.

Shapiro, D., \& Globerman, S. J. M., Simon Fraser University. (2001). National infrastructure and foreign direct investment.

Treviño, L. J., \& Mixon Jr, F. G. J. J. o. w. b. (2004). Strategic factors affecting foreign direct investment decisions by multi-national enterprises in Latin America. 39(3), 233-243.

Villela, L. A., \& Barreix, A. D. (2002). Taxation and Investment promotion. Retrieved from

Wang, Z. Q., \& Swain, N. J. J. W. A. (1995). The determinants of foreign direct investment in transforming economies: Empirical evidence from Hungary and China. 131(2), 359-382.

Welfens, P. J. J. (1994). Foreign Direct Investment and Privatization.

\section{Webography}

https://www.gipcghana.com/invest-in-ghana/doing-business-in-ghana/laws-regulation.html 